\title{
The Effect of Various pH Medium on the Secondary Metabollites Production from Trichoderma harzianum T10 to Control Damping Off on Cucumber Seedlings
}

\author{
Nur Chalimah1, Loekas Soesanto', Woro Sri Suharti*1 \\ ${ }^{1}$ Department of Agrotechnology, Faculty of Agriculture, Universitas Jenderal Soedirman \\ Jl. Dr. Soeparno No 73, Purwokerto 53122, Indonesia \\ *Corresponding author: woro.suharti@unsoed.ac.id
}

\section{ARTICLE HISTORY}

Received : 18 July 2020

Revised : 27 August 2020

Accepted : 12 September 2020

\section{KEYWORDS}

Cucumber;

pH Medium;

Secondary Metabolites;

T. harzianum;

\begin{abstract}
Damping-off is one of the main diseases in cucumber seedlings caused by Pythium sp. Secondary metabolites of Trichoderma harzianum T10 can conduct the control of the disease. The $\mathrm{pH}$ of the medium influences the production of secondary metabolites. The research aimed to determine the effective $\mathrm{pH}$ medium on production of T. harzianum T10 secondary metabolites, and the effect of the T. harzianum T10 secondary metabolites application in damping-off disease control also to the growth of cucumber seedling. The research was consist of two steps; 1 ) in vitro assay with various $\mathrm{pH}$ levels $5 ; 3 ; 3.5 ; 4 ; 4.5 ; 5.5 ; 6 ; 6.5$; and 7,2 ) In planta treatments consisted of control, fungicide (Mancozeb), secondary metabolites in pH 5 and 5.5 with the concentration of 5, 10 and $15 \%$ each. The research showed that: 1) the effective pH medium for the production of T. harzianum T10 secondary metabolites was 5 and 5.5. 2) application of the T. harzianum T10 secondary metabolites on pH 5 and 5.5 with a concentration of 5,10 , and $15 \%$ could decrease the disease incidence and support cucumber seedling growth.
\end{abstract}

This is an open-access article under the CC-BY-SA license.

\section{INTRODUCTION}

Cucumber (Cucumis sativus L.) is one vegetable that has been widely consumed in Indonesia. Cucumber cultivation in Indonesia may decrease production due to a number of obstacles, including environmental mismatches, improper cultivation technology, and pests and pathogens existence. This occurrence affected low cucumber growth and production. One of the important diseases in cucumber plants is the seedling disease caused by Pythium sp.

Some efforts to control the Pythium sp. have been conducted (Halo, et al., 2019). However, the utilizing of biological agents is considered to be the most effective and environmentally friendly. According to Kamala \& Indira (2011), biological agents' secondary metabolites, such as Trichoderma spp. can be used to control the Pythium sp. It is well-known that Trichoderma spp. is antagonistic fungi for several pathogens (Naher, et al., 2017; Suada, 2017). One of Trichoderma species which widely used is T. harzianum. This fungal antagonist produces a secondary metabolite with the potential ability to suppress plant pathogens' development (Li, et al., 2019). Generally, the biosynthesis of the secondary metabolites of mycoparasitic fungi is influenced by the $\mathrm{pH}$ condition (Speckbacher \& Zeilinger, 2018). Based on these reasons, it is necessary to observe the T. harzianum medium's appropriate $\mathrm{pH}$ to obtain the highest secondary metabolites production.

This study aims to determine (1) the most suitable $\mathrm{pH}$ of the medium for $T$. harzianum T10 secondary metabolites production, (2) the effect of T. harzianum T10 secondary metabolites application to control damping-off disease, and (3) the effect of T. harzianum T10 secondary metabolites application to cucumber plant growth.

\section{MATERIALS AND METHODS}

The research was conducted from November 2018 to March 2019 in 2 stages, in vitro at the Plant Protection Laboratory and planta at screen house Faculty of Agriculture, Universitas Jenderal Soedirman, Purwokerto.

\subsection{In-vitro Assay}

Isolation of Pythium sp. Pythium sp. isolated by grows cucumber seeds in cow dung. Further, the parts of plants infected with Pythium sp. were isolated.

Preparation of $\boldsymbol{T}$. harzianum. The antagonist used is a fungus of T. harzianum T10 obtained from the collection 
of Plant Protection Laboratory. The fungus was cultured by using aseptically in Laminar Air Flow (LAF), incubated for seven days.

Secondary Metabolites Preparation. Secondary metabolites of $T$. harzianum were prepared in Potato Dextrose Broth (PDB) medium. The acidity levels were regulated according to the treatment (3-7) by adding 0.1 $\mathrm{N}$ HCL or $\mathrm{NaOH}$. The $150 \mathrm{~mL}$ of PDB were inoculated with 3 cork drill of T. harzianum aseptically. Medium added by T. harzianum was shaken using an orbital shaker for seven days at $1500 \mathrm{rpm}$ at room temperature.

Conidium density. Conidium density was calculated using the formula as follow:

$$
\mathrm{S}=\frac{t \times \mathrm{d}}{\mathrm{N} \times 0,0025} \times 10^{-6}
$$

Where:

$$
\begin{array}{ll}
\mathrm{S} & =\text { conidium density } \\
\mathrm{t} & =\text { number of spores in haemocytometer } \\
& \begin{array}{c}
\text { counting } \\
\text { box }
\end{array} \\
\mathrm{d} & =\text { dilution rate } \\
\mathrm{N} & =\text { number of haemocytometer calculated boxes } \\
0.0025 & =\text { volume of spore suspension } \\
10^{-6} & =\text { constants }
\end{array}
$$

Chitinase Enzym Assay. Chitinase assay was carried out qualitatively by using chitin agar medium. The chitin agar medium's composition consists of $2 \%$ colloidal chitin, $0.1 \%$ K2HPO4, 001\% MgSO4.7. H2O, 3\% NaCl, 0.7\% (NH4) 2 S0 $4,0.05 \%$ yeast extract, $2 \%$ agar, and $1 \mathrm{~L}$ distilled water. The presence of the chitinase enzyme is characterized by the formation of a clear zone in the medium.

ß-1,3-glucanase Assay. The examination to determine ß-1,3-glucanase was conducted qualitatively by the agar diffusion method. The $0.3 \mathrm{~g}$ agarose solution was dissolved in $29 \mathrm{ml}$ of distilled water and added with $1 \mathrm{ml}$ of a sub-glucan substrate. The presence of the $ß$-1,3-glucanase enzyme is characterized by the formation of a clear zone in the medium.

Inhibition Ability. The inhibition ability was calculated using the formula as follow:

$$
\mathrm{PP}=\frac{\mathrm{R} 1-\mathrm{R} 2}{R 1} \times 100 \%
$$

Where:

$$
\begin{aligned}
\text { PP = } & \text { Percent Inhibition }(\%), \\
\text { R1 = } & \text { Radius of pathogenic colonies which evade from } \\
& \text { biological agent colonies } \\
\text { R2 = } & \text { Radius of pathogenic colonies which approached } \\
& \text { colonies of biological agents }
\end{aligned}
$$

\subsection{In-planta Assay}

Germination growth examination. The examination was carried out by growing cucumber seeds that soaked in $\mathrm{T}$. harzianum secondary metabolites treatment at various $\mathrm{pH}$ levels, then grown on a petri dish inserted with filter paper moistened with sterile water. The observation was made by measuring the growth of roots and canopies on germinated cucumber seeds. Observations were implemented on the 7 th day after planting. Percent germination is calculated using the formula as below:

$$
\mathrm{DB}=\frac{\sum \text { normal sprouts }}{\sum \text { germinated seed }} \times 100 \%
$$

Pythium sp. inoculation in cucumber plants and the application of secondary metabolites $T$. harzianum T10. Pythium sp. inoculated by insert 3 cork drills of Pythium sp. culture on the soil media. Cucumber seeds are placed on top of soil media. The secondary metabolites of T. harzianum with a density of $10^{-6}$ poured on cucumber seeds as much as $10 \mathrm{ml} /$ plant every five days.

Disease incidence. Disease incidence was calculated using the formula:

$$
\mathrm{KP}=\frac{\sum \text { plant with symptom }}{\sum \text { total number of plants }} \times 100 \%
$$

AUDPC. The AUDPC calculated using the formula as follow:

$$
\operatorname{AUDPC}=\sum_{\mathrm{i}}^{\mathrm{n}-1}\left|\frac{\mathrm{Y}_{\mathrm{i}}+\mathrm{Y}_{\mathrm{i}}+1}{2}\right|\left(\mathrm{t}_{1}+1-\mathrm{t}_{\mathrm{i}}\right)
$$

Where:

AUDPC = Disease development curve,

$\mathrm{Y}_{\mathrm{i}}+1=$ observational data to $\mathrm{i}+1$

$\mathrm{Y}_{\mathrm{i}}=$ observational data to 1

$\mathbf{t}_{\mathrm{i}}+\mathbf{1}=$ observational time to $\mathrm{i}+1$,

$\mathbf{t}_{\mathrm{i}}=$ observational time to 1 .

\section{RESULTS AND DISCUSSIONS}

\subsection{In Vitro Assay}

Based on the study results, the density of conidium $T$. harzianum $\mathrm{T} 10$ in the treatment of several $\mathrm{pH}$ mediums showed a difference (Table 1). The highest conidium density was reached by $\mathrm{pH}$ medium 5 as control (K0). All secondary metabolites of T. harzianum T10 grown on different $\mathrm{pH}$ medium showed that the secondary metabolites of T. harzianum shaken for seven days could grow in a medium $\mathrm{pH}$ 3-7. Meanwhile, the suitable $\mathrm{pH}$ medium to optimize T. harzianum is pH 5-7 (Singh, et al., 2018).

Various $\mathrm{pH}$ of secondary metabolites medium $T$. harzianum significantly affects inhibitory ability (Tabel 1). The highest inhibition was found in the treatment with medium pH5 (K0), followed by the medium with $\mathrm{pH} 5.5$ (K5) with percentage inhibition as $76.8 \%$ and $75.6 \%$. It suggested that the secondary metabolites of T. harzianum have the ability to inhibit the growth of Pythium sp. This growth inhibition is proposed as an antibiosis reaction by 
the secondary metabolites compound of $\mathrm{T}$. harzianum. Microscopic observations showed a change in Pythium sp. hyphae structure (Figure 1). The structure distortion of pathogens hyphae were occurred due to antagonistic activity through an antibiosis mechanism (Naglot, et al., 2015).

As shown in Table 1, the germination data explained that all treatments showed a high percentage of germination. It is probably caused by the use of healthy seeds with good viability, which is certified with high standards from the seed producer. According to Soares, et al. (2019), cucumber seed germination interfered with seeds' health quality.

Table 1. In-vitro observation towards conidium density, inhibition ability, and germination

\begin{tabular}{lcccc}
\hline Treatment & $\begin{array}{c}\text { Density of } \\
\text { conidium x } \\
10^{7}\end{array}$ & $\begin{array}{c}\text { Inhibition } \\
\text { ability } \\
(\%)\end{array}$ & $\begin{array}{c}\text { Germination } \\
\text { conidium } / \mathrm{mL}\end{array}$ \\
\hline K0 (pH 5) & 10.90 & 76.80 & $\mathrm{~d}$ & $96.67 \mathrm{a}$ \\
K1 (pH 3) & 0.27 & 58.07 & $\mathrm{ab}$ & $96.67 \mathrm{a}$ \\
K2(pH 3.5) & 1.30 & $51.93 \mathrm{a}$ & $96.67 \mathrm{a}$ \\
K3 (pH 4) & 2.20 & $58.10 \mathrm{ab}$ & $96.67 \mathrm{a}$ \\
K4 (pH & 4.60 & 51.20 & $\mathrm{a}$ & $90.00 \mathrm{a}$ \\
$4.5)$ & 4.20 & $75.60 \mathrm{~d}$ & $93.33 \mathrm{a}$ \\
K5 (pH 5.5) & 3.08 & 67.67 & $\mathrm{~d}$ & $100.00 \mathrm{a}$ \\
K6 (pH 6) & 2.70 & 62.53 & $\mathrm{bc}$ & $90.00 \mathrm{a}$ \\
K7(pH 6.5) & 1.70 & $56.00 \mathrm{ab}$ & $96.67 \mathrm{a}$ \\
K8 (pH 7) & & &
\end{tabular}

Figures followed by different letters in the same column show significantly different DMRT test probability levels 5\%.

In Table 2, the secondary metabolites medium with a $\mathrm{pH}$ between 4.5 to 7 could produce enzyme $ß-1,3$-glucanase. Robinson (2015) found that enzyme activity is influenced by $\mathrm{pH}$. In the case of $ß-1,3$-glucanase, it is suspected that a high acidic $\mathrm{pH}$ will cause cell metabolism disrupted, and a low $\mathrm{pH}$ condition causes the enzyme to work improperly.

Table 2. The content of enzyme $ß-1,3$-glucanase and chitinase qualitatively

\begin{tabular}{lcc}
\hline \multicolumn{1}{c}{ Treatment } & ß-1,3-glucanase & Chitinase \\
\hline K0 (pH 5) & ++ & ++ \\
K1 (pH 3) & - & - \\
K2 (pH 3.5) & - & - \\
K3 (pH 4) & - & - \\
K4 (pH 4.5) & ++ & + \\
K5 (pH 5.5) & ++ & ++ \\
K6 (pH 6) & ++ & + \\
K7 (pH 6.5) & +++ & +++ \\
K8 (pH 7) & +++ & ++ \\
\hline
\end{tabular}

Note: $(-)=$ none, $(+)=$ little, $(++)=$ a large amount, $(+++)=$ much.

Figure 1. Antibiosis mechanism of T. harzianum against Pythium sp. with 400x magnification

As shown in Table 2, the secondary metabolites medium $\mathrm{pH}$ T. harzianum $\mathrm{T} 10$ with range 4.5 to 7 could produce chitinase enzymes. Hamid et al. (2014)

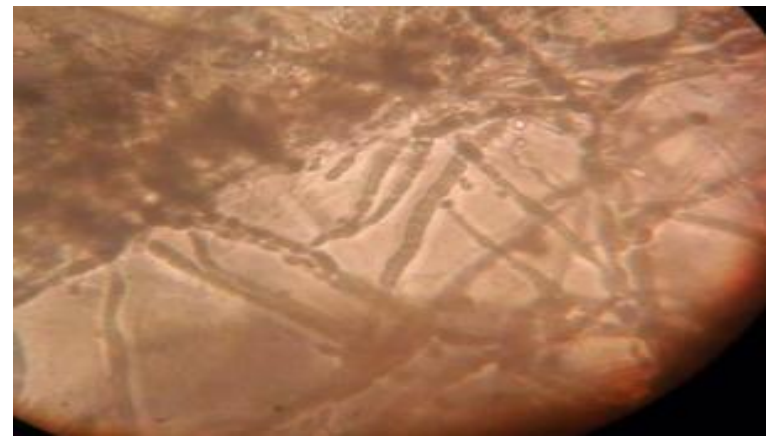

explained that the chitinase enzyme's optimum activity lay on a $\mathrm{pH}$ range 5 to 7 . Meanwhile, the stability of the chitinase enzyme is laid on a $\mathrm{pH}$ range between 4 and 8 .

Table 3 showed that all treatments had a longer root than the canopy. It is suspected that the secondary metabolites of $\mathrm{T}$. harzianum can produce growth regulators, such as hormones that can stimulate plant growth. This is in accordance with the opinion of Haneefat, et al. (2012), that application of T. harzianum secondary metabolites can increase gibberellins in plant roots. According to Bidadi, et al. (2010), the increase of adventitious and primary root length is caused by hormones' influence. Gibberellin hormone will support the formation of proteolysis enzymes, which will release a tryptophan as a precursor of auxin. It implied that gibberellins would increase the content of auxin, which induces rooting. The less optimum role of auxin hormones is due to certain compounds produced from the hormone gibberellin, which can be inhibitory. Therefore, the role of auxin is being interrupted.

Table 3. Effect the $\mathrm{pH}$ of the medium towards seed growth

\begin{tabular}{lcc}
\hline Treatment & Root $(\mathrm{cm})$ & Canopy $(\mathrm{cm})$ \\
\hline K0 (pH 5) & 14.40 & 10.27 \\
K1 (pH 3) & 13.90 & 11.20 \\
K2 (pH 3.5) & 15.93 & 10.30 \\
K3 (pH 4) & 13.57 & 10.43 \\
K4 (pH 4.5) & 11.43 & 10.23 \\
K5 (pH 5.5) & 13.83 & 10.93 \\
K6 (pH 6) & 11.63 & 9.83 \\
K7 (pH 6.5) & 12.83 & 10.40 \\
K8 (pH 7) & 13.00 & 9.13 \\
\hline
\end{tabular}

\subsection{In-planta Assay}

Research result in planta showed that the incubation period of $T$. harzianum secondary metabolites with various concentrations showed significant results compared with $\mathrm{K}$ treatment (Tabel 4). The treatments of various concentrations were able to lengthen the incubation period of Pythium sp. as $84.82 \%$ against control.

The application of mancozeb (F) showed similar effects with other treatment methods toward the incubation period (Tabel 4). Presumably, the active 
ingredient of mancozeb can suppress the infections of a pathogen. Therefore, the growth of pathogens is inhibited. This statement is in accordance with Gullino, et al. (2010), the mancozeb is a broad-spectrum fungicide that appropriates to control the fungal pathogen.

The incubation periods of all treatments of $T$. harzianum secondary metabolites in various concentrations were 42 days after inoculation. It showed that all treatments could suppress an incubation period of up to $100 \%$. This evidence is in accordance with the opinion of Vinale, et al. (2014), a biological agent able to inhibit and control the pathogens by using secondary

Table 4. The effect of treatment toward pathology system component

\section{Treatment}

metabolites.

Based on the results, all treatments, including fungicide application, had a similar effect on disease incidence than control (Table 4). The activeness suspects the high disease incidence percentage in the control treatment of pathogens that are more adaptable and infectious to the plants. It is in accordance with Islam (2018), the occurrence of a disease is influenced by virulent pathogens, a conducive environment, and susceptible host plants. The interaction of those factors at the same time increases the development of the disease.

\begin{tabular}{|c|c|c|}
\hline Treatment & $\begin{array}{l}\text { The incubation period } \\
\text { (days after incubation) }\end{array}$ & $\begin{array}{l}\text { Disease incidence } \\
(\%)\end{array}$ \\
\hline K (without secondary metabolites application) & $6.38 \mathrm{a}$ & $58.33 \mathrm{~b}$ \\
\hline $\mathrm{F}($ mancozeb) & $32.50 \mathrm{~b}$ & $8.33 \mathrm{a}$ \\
\hline A1 (secondary metabolites pH 5 concentration 5\%) & $42.00 \mathrm{~b}$ & 0 a \\
\hline A2 (secondary metabolites pH 5 concentration 10\%) & $42.00 \mathrm{~b}$ & 0 a \\
\hline A3 (secondary metabolites pH 5 concentration 15\%) & $42.00 \mathrm{~b}$ & 0 a \\
\hline B1 (Secondary metabolites pH 5.5 concentration 5\%) & $42.00 \mathrm{~b}$ & 0 a \\
\hline B2 (Secondary metabolites pH 5.5 concentration 10\%) & $42.00 \mathrm{~b}$ & 0 a \\
\hline B3 (Secondary metabolites pH 5.5 concentration 15\%) & $42.00 \mathrm{~b}$ & 0 a \\
\hline
\end{tabular}

Figures followed by different letters in the same column show significantly different from the DMRT test with an error rate of $5 \%$. Data on disease incidence were transformed into $\sqrt{x}+0.5$.

The AUDPC is directly proportional to the disease incidence and incubation period (Figure 2). The control showed the highest disease incidence rate and the shortest incubation period. It is thought to be due to the absence of secondary metabolites of $T$. harzianum. Therefore, the suppression of the development of Pythium sp. does not occur. Meanwhile, T. harzianum secondary metabolites' application showed low AUDPC value, which was suggested as effective treatments to control Pythium sp.

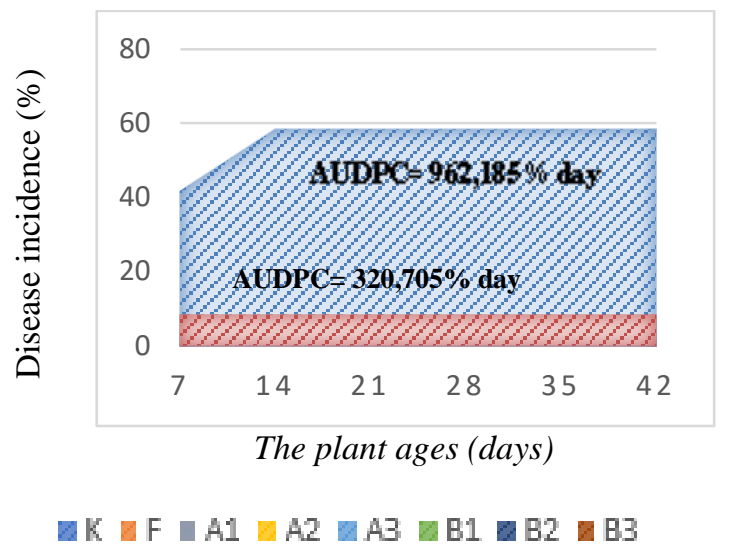

Figure 2. The disease incidence of cucumber plants damping-off and AUDPC values.

Note: $\mathrm{K}=$ Control, $\mathrm{F}=$ Fungicide (mancozeb), $\mathrm{A} 1=\mathrm{pH} 5$ concentration $5 \%, \mathrm{~A} 2=\mathrm{pH} 5$ concentration $10 \%, \mathrm{~A} 3=\mathrm{pH} 5$ concentration 15\%, B1 = pH 5.5 concentration 5\%, B2 = pH 5.5 concentration 10\%, and B3 = pH 5.5 concentration $15 \%$. The applications of secondary metabolites T. harzianum T10 were able to increase the plant height by the A1, A2, 
A3, B1, B2, and B3 treatments as 53.85\%, 55.1\%, 58.23\%, $62.19 \%, 56.02 \%$, and $54.98 \%$, respectively (Table 5). The highest plant height was the B1 treatment. It is suggested that the secondary metabolites produced by T. harzianum are anti-fungal, which inhibit pathogen growth. Therefore, the plant's physiological processes, such as the translocation of nutrients from the soil to plants, are not disturbed. According to Marques, et al. (2018), the inhibition mechanism of fungal antagonists is caused by producing anti-fungal compounds.

Based on Tabel 5, the application of T. harzianum secondary metabolites in $\mathrm{A} 1, \mathrm{~A} 2, \mathrm{~A} 3, \mathrm{~B} 1, \mathrm{~B} 2$, and $\mathrm{B} 3$ treatments increased the number of leaves by $40.63 \%$, $38.7 \%, \quad 42.42 \% \quad 53.66 \%, 44.12 \%$, and $44.12 \%$, respectively. It is proposed that the application of $\mathrm{T}$. harzianum secondary metabolites can stimulate plant growth. Halifu, et al. (2019) revealed that T. harzianum can degrade soil macronutrients to effective plant demand, such as nitrogen. The nitrogen itself has functions to stimulate plant growth and develop a green color to the leaves to increase plant photosynthesis.

As shown in Table 5, cucumber plants with $T$. harzianum secondary metabolites application had a longer root length than control (K). The shortest of cucumber plant root with control treatment is thought to be due to pathogen infection damage. Further, the infected root can inhibit plant growth and trigger plant death (Schroeder, et al., 2013). All applications of $T$. harzianum secondary metabolites were able to increase the root length in $\mathrm{A} 1, \mathrm{~A} 2, \mathrm{~A} 3, \mathrm{~B} 1, \mathrm{~B} 2$, and $\mathrm{B} 3$ treatment as $61.58,63.49,62.95,68.05,67.7$, and $56.57 \%$, respectively. This occurrence revealed that $T$. harzianum secondary metabolites could produce enzymes to damage the cell wall of pathogenic fungi. Furthermore, it can inhibit the development of pathogens in plant tissues. Finally, the pathogens disable to infect plant roots. This occurrence is in accordance with the opinion of Vinale, et al. (2014). The secondary metabolites of T. harzianum are antibiotics, enzymes, and toxins that can inhibit pathogens in plant tissues with various mechanisms.

Based on the results as shown in Table 5, the application of secondary metabolites of T. harzianum was able to increase the fresh weight of plants in treatments A1, A2, A3, B1, B2, and B3 as 60.25, 69.3, 66.48, 71.39, 70.52 , and $70.32 \%$, respectively. The occurrence was also identified by Ortuño, et al. (2017) in several plants such as lettuce, radish, and quinoa. The increase of biomass is suggested as an effect of cell division, expansion, and differentiation of fungal auxin-like compounds, besides improving plant nutrient uptake (Contreras-Cornejo, et al.. 2017).

Table 5. Effect of treatment on plant growth components

\begin{tabular}{lrrrrrrrr}
\hline \multicolumn{1}{c}{ Treatment } & $\begin{array}{c}\text { Plant height } \\
(\mathrm{cm})\end{array}$ & $\begin{array}{c}\text { Number of } \\
\text { Leaves }\end{array}$ & \multicolumn{2}{c}{ Root length (cm) } & \multicolumn{2}{c}{$\begin{array}{c}\text { Fresh weight of } \\
\text { crops (g) }\end{array}$} \\
\hline $\begin{array}{l}\text { K (without secondary metabolites } \\
\text { application) }\end{array}$ & 55.69 & $\mathrm{a}$ & 9.50 & $\mathrm{a}$ & 13.43 & $\mathrm{a}$ & 14.66 & $\mathrm{a}$ \\
\hline F (mancozeb) & 131.00 & $\mathrm{~b}$ & 18.25 & $\mathrm{~b}$ & 34.25 & $\mathrm{~b}$ & 44.92 & $\mathrm{~b}$ \\
\hline $\begin{array}{l}\text { A1 (secondary metabolites pH 5 } \\
\text { concentration 5\%) }\end{array}$ & 120.67 & $\mathrm{~b}$ & 16.00 & $\mathrm{~b}$ & 34.96 & $\mathrm{~b}$ & 36.83 & $\mathrm{~b}$ \\
\hline $\begin{array}{l}\text { A2 (secondary metabolites pH 5 } \\
\text { concentration 10\%) }\end{array}$ & 124.04 & $\mathrm{~b}$ & 15.50 & $\mathrm{~b}$ & 36.54 & $\mathrm{c}$ & 47.75 & $\mathrm{~b}$ \\
\hline $\begin{array}{l}\mathrm{A} \text { 3 (secondary metabolites pH 5 } \\
\text { concentration 15\%) }\end{array}$ & 133.29 & $\mathrm{~b}$ & 16.50 & $\mathrm{~b}$ & 36.25 & $\mathrm{c}$ & 43.73 & $\mathrm{~b}$ \\
\hline $\begin{array}{l}\text { B1 (Secondary metabolites pH 5.5 } \\
\text { concentration 5\%) }\end{array}$ & 147.29 & $\mathrm{~b}$ & 20.50 & $\mathrm{~b}$ & 42.03 & $\mathrm{c}$ & 51.24 & $\mathrm{~b}$ \\
\hline $\begin{array}{l}\text { B2 (Secondary metabolites pH 5.5 } \\
\text { concentration 10\%) }\end{array}$ & 126.63 & $\mathrm{~b}$ & 17.00 & $\mathrm{~b}$ & 41.58 & $\mathrm{c}$ & 49.73 & $\mathrm{~b}$ \\
\hline $\begin{array}{l}\text { B3 (Secondary metabolites pH 5.5 } \\
\text { concentration 15\%) }\end{array}$ & 123.69 & $\mathrm{~b}$ & 17.00 & $\mathrm{~b}$ & 44.13 & $\mathrm{c}$ & 49.39 & $\mathrm{~b}$ \\
\hline
\end{tabular}

Figures followed by different letters in the same column show significantly different from the DMRT test with a probability level of $5 \%$. Data on plant height, number of leaves and fresh weight of plants were transformed to $\sqrt{x}$

\section{CONCLUSIONS}

1. The appropriate $\mathrm{pH}$ medium for the production of $\mathrm{T}$. harzianum T10 secondary metabolites were $\mathrm{pH} 5$ and 5.5 .

2. Application of the $\mathrm{T}$. harzianum $\mathrm{T} 10$ secondary metabolites on $\mathrm{pH} 5$ and 5.5 with a concentration of 5 , 10 , and $15 \%$ could decrease the disease incidence.

3. Application the $\mathrm{T}$. harzianum $\mathrm{T} 10$ secondary metabolites on pH 5 and 5.5 with a concentration of 5 , 10 , and $15 \%$ could increase crop height, the number of leaves, root lengths, and fresh crop weight. 


\section{REFERENCES}

Bidadi, H., Yamaguchi, S., Asahina, M., \& Satoh, S. (2010). Effects of shoot-applied gibberellin/gibberellin-biosynthesis inhibitors on root growth and expression of gibberellin biosynthesis genes in Arabidopsis thaliana. Plant Root, 4, 4-11.

Contreras-Cornejo, H. A., Macías-Rodríguez, L., del-Val, E., \& Larsen, J. (2016). Ecological functions of Trichoderma spp. and their secondary metabolites in the rhizosphere: interactions with plants. FEMS microbiology ecology, 92(4), fiw036.

Gullino, M. L., Tinivella, F., Garibaldi, A., Kemmitt, G. M., Bacci, L., \& Sheppard, B. (2010). Mancozeb: past, present, and future. Plant Disease, 94(9), 1076-1087.

Halifu, S., Deng, X., Song, X., \& Song, R. (2019). Effects of Two Trichoderma Strains on Plant Growth, Rhizosphere Soil Nutrients, and Fungal Community of Pinus sylvestris var. mongolica Annual Seedlings. Forests, 10(9), 758.

Halo, B. A., Al-Yahyai, R. A., Maharachchikumbura, S. S., \& Al-Sadi, A. M. (2019). Talaromyces variabilis interferes with Pythium aphanidermatum growth and suppresses Pythium-induced damping-off of cucumbers and tomatoes. Scientific reports, 9(1), $1-10$.

Hamid, R., Khan, M. A., Ahmad, M., Ahmad, M. M., Abdin, M. Z., Musarrat, J., \& Javed, S. (2013). Chitinases: an update. Journal of pharmacy \& bioallied sciences, 5(1), 21.

Haneefat, O. E., Sobowale, A. A., Ilusanya, O. A. F., \& Feyisola, R. T. (2012). The influence of Glomus mosseae and Trichoderma harzianum on phytohormone production in soybeans (Glycine max L. Merr) planted in sterilized and unsterilized soils. Journal of Experimental Agriculture International, 516-524.

Islam, W. (2018). Plant disease epidemiology: disease triangle and forecasting mechanisms in highlights. Hosts and Viruses, 5(1), 7-11.

Kamala, T., \& Indira, S. (2011). Evaluation of indigenous Trichoderma isolates from Manipur as biocontrol agent against Pythium aphanidermatum on common beans. 3 Biotech, 1(4), 217-225.

Li, M. F., Li, G. H., \& Zhang, K. Q. (2019). Non-volatile metabolites from Trichoderma spp. Metabolites 9: 58.
Marques, E., Martins, I., \& Mello, S. C. M. D. (2018). Antifungal potential of crude extracts of Trichoderma spp. Biota Neotropica, 18(1).

Naglot, A., Goswami, S., Rahman, I., Shrimali, D. D., Yadav, K. K., Gupta, V. K., ... \& Veer, V. (2015). Antagonistic potential of native Trichoderma viride strain against potent tea fungal pathogens in North East India. The plant pathology journal, 31(3), 278.

Naher, L., Yusuf, U. K., Ismail, A., \& Hossain, K. (2014). Trichoderma spp.: a biocontrol agent for sustainable management of plant diseases. Pak. J. Bot, 46(4), 1489-1493.

Ortuño, N., Castillo, J. A., Miranda, C., Claros, M., \& Soto, X. (2017). The use of secondary metabolites extracted from Trichoderma for plant growth promotion in the Andean highlands. Renewable Agriculture and Food Systems, 32(4), 366-375.

Robinson, P. K. (2015). Correction: Enzymes: principles and biotechnological applications. Essays in Biochemistry, 59, 75-75.

Schroeder, K. L., Martin, F. N., de Cock, A. W., Lévesque, C. A., Spies, C. F., Okubara, P. A., \& Paulitz, T. C. (2013). Molecular detection and quantification of Pythium species: evolving taxonomy, new tools, and challenges. Plant Disease, 97(1), 4-20.

Speckbacher, V., \& Zeilinger, S. (2018). Secondary metabolites of mycoparasitic fungi.Secondary Metabolites: Sources and Applications, 37.

Soares, V. N., Villela, F. A., Radke, A. K., Rodrigues, H. C. S., Gonçalves, V. P., \& Meneghello, G. E. (2019). Influence of physiological and health quality on the vigor of cucumber seeds. Arquivos do Instituto Biológico, 86.

Suada, I. K. (2017). The potential of various indigenous Trichoderma spp. to suppress Plasmodiophora brassicae the pathogen of clubroot disease on cabbage. Biodiversitas Journal of Biological Diversity, 18(4), 1424-1429.

Vinale, F., Sivasithamparam, K., Ghisalberti, E. L., Woo, S. L., Nigro, M., Marra, R., ... \& Manganiello, G. (2014). Trichoderma secondary metabolites active on plants and fungal pathogens. The Open Mycology Journal, 8(1). 